Jurnal Penelitian Hasil Hutan

Forest Products Research Journal.

Vol 11, No. 4 (1993) pp. 153-156

\title{
PENGARUH PEMANENAN HASIL HUTAN TERHADAP TINGKAT KERUSAKAN TEGAKAN TINGGAL PADA DUA HAK PENGUSAHAAN HUTAN (HPH) DI KALIMANTAN BARAT \\ (The effect of logging to residual stand damages in two forest concessions in West Kalimantan)
}

\author{
Oleh/By \\ Sona Suhartana
}

Summary

Disturbed soil and vegetation caused by logging operation is difficult to be avoided, even in good logging operation.

Past studies related to this problem. shows that forest concessions in Sumatera and Kalimantan used Indonesia Selective Cutting System (TPTI) as a basic activity in logging operation. However, because of the weakness of goverment control activity, most of the companies were looking for financial benefit only and neglect the sustainability of the forest.

The aim of this study is to assess the number of commercial trees (diameter $20 \mathrm{~cm}$ and up) damaged during logging operation.

The study was carried out in two forest concessions : PT. Batasan/A and PT. Tanjungpura Bhakti/B in West Kalimantan

The results shows that :

1. The average percentage of commercial trees damaged of diameter $20 \mathrm{~cm}$ and up during logging operation are $4.6 \%$ in $\mathrm{A}$ concession and $5.6 \%$ in B concession.

2. The average number of trees in concession $A$ are 8.9 trees/ha while in concession $B$ is 7.8 trees/ha.

\section{PENDAHULUAN}

Kegiatan pemanenan hasil hutan merupakan kunci yang memegang peranan penting dalam mata rantai kegiatan pendayagunaan sumberdaya hutan, tetapi di negara-negara sedang berkembang justru kegiatan ini yang terlemah (Letourneau, 1979).

Ewel \& Conde (1978) berpendapat bahwa, dalam pemanenan hasil hutan tropika basah akan ditemukan dampak terhadap beberapa bidang, yaitu :

- Tanah dan unsur hara, meliputi așpek fisik dan kimia tanah serta jasad renik.

- Sumber air, mencakup kuantitas dan kualitasnya.

- Vegetasi, meliputi tegakan tinggal dan plasma nutfah.

- Satwa liar, mencakup perubahan habitat dan kesinambungan hidupnya.

Guna menjamin kelestarian produksi hutan, harus ditentukan sistem silvikultur yang tepat untuk setiap areal berdasarkan pertimbangan ekonomis dan ekologis yang seimbang. Pertimbangan pokok sistem tersebut untuk aspek ekologi, adalah akan menimbulkan perubahan ekosistem alami yang kecil. Dari segi ekonomi diharapkan dapat mencapai hasil (output) yang sebesar-besarnya dengan masukan (input) yang memadai.

Dengan memperhatikan pertimbangan pokok kedua aspek tersebut di atas, maka sampai saat ini sistem
Tebang Pilih Tanam Indonesia (TPTI) dipandang sebagai suatu sistem silvikultur yang sesuai untuk diterapkan dalam pengusahaan hutan alam produksi tropika basah.

Dalam sistem TPTI ditentukan persyaratan tersedianya sejumlah pohon inti berdiameter di atas limit diameter tertentu. Misalnya untuk rotasi penebangan 35 tạhun dan diameter terkecil pohon yang dipungut. 50 $\mathrm{cm}$, guna menjaga kelestarian produksi periode berikutnya diperlukan 25 pohon inti berdiameter $35 \mathrm{~cm}$ ke atas per hektarnya tersebar merata di areal bekas tebangan.

Dewasa ini terdapat kekhawatiran akan keseimbangan produktivitas hutan bila pemanenan hasil hutan secara mekanis terus berlangsung. Kekhawatiran termaksud mencakup masalah hutan produksi dan keberadaannya yang saling terkait agar tetap diperoleh secara proporsional antara keuntungan perusahaan dan kelestarian sumberdaya hutan.

Pemanenan hasil hutan betapapun hati-hatinya dilaksanakan; namun kerusakan terhadap vegetasi dan tanah yang timbul tidak mungkin dapat dihindari sepenuhnya.

Hasil peneltian dalam Thaib (1985) mengemukakan bahwa kegiatan pemanenan hasil hutan dengan sistem traktor mengakibatkan kerusakan tegakan tinggal sebesar 3,8 \% sampai 50,8 \% per hektar untuk' jenis perdagangan. Selanjutnya penulis tersebut menyatakan bahwa, penurunan pohon berdiameter $20 \mathrm{~cm}$ ke atas 
terjadi antar $11,7 \%$ sampai $31,8 \%$ untuk penebangan 5 sampai 9 pohon/ha.

Lebih lanjut hasil peneltian dalam Thaib (1985, 1986a, 1986b) berkesimpulan bahwa: secara resmi semua Hak Pengusahaan Hutan (HPH) yang diteliti yang berlokasi di Sumatra (Riau, Sumatra Barat, Jambi, Sumatra Selatan) dan Kalimentan (Kalimantan Tengah) pada dasarnya menganut sistem silvikultur TPTI sebagai landasan panduan pelaksapaan kegiatan pemanenan hasil hutan. Namun karena kegiatan pengawasan masih lemah, menyebabkan kegiatan pengusahaan hutan cenderung mementingkan asas keuntungan perusahaan.

Berdasarkan permasalahan seperti telah dijelaskan dimuka, dalam penelitian ini dilakukan suatu kajian yang bertujuan untuk mengetahui derajat kerusakan tegakan tinggal yang terjadi (pohon berdiameter $20 \mathrm{~cm}$ dan ke atas) di kawasan HPH serta pengaruh faktor jumlah pohon ditebang per satuan luas.

\section{METODE PENELITIAN}

\section{A. Lokasi Peneltian}

Penelitan ini dilaksanakan pada dua areal HPH, yaitu PT Batasan (HPH A) dan PT Tanjung Pura Bhakti (HPH B) yang keduanya termasuk ke dalam wilayah Propinsi/ DATI I Kalimantan Barat.

\section{B. Bahan dan Alat}

Bahan atau objek dalam penelitian ini adalah tegakan tinggal berupa blok-blok bekas tebangan terbaru yang termasuk dalam rencana Karya Tahunan (RKT) tahun 1992/1993.

Peralatan yang digunakan antara lain : peta kerja perusahaan, kompas, peralatan ukur lereng dan tinggi tempat serta jarak dan diameter pohon, blanko-blanko peta Tree Location Plan (TLP) berskala 1:500 berikut kelengkapannya.

\section{Penarikan Contoh}

- Unit contoh berbentuk persegi empat dengan ukuran luas 1 ha (100 m $\times 100 \mathrm{~m})$.

- Unit contoh ditempatkan dengan cara acak untuk unit pertama dan sistematis untuk unit contoh berikutnya.

- Dari tiap unit contoh, semua pohon berdiameter 20 cm ke atas, nama pohon, ukuran diameter dan keadaannya serta semua bokas jalan sarad dipetakan pada blanko peta TLP.

Tunggak-tunggak pohon yang ditebang juga dipetakan untuk mengetahui jumlah pohon yang ditebang per unit contoh. Di samping itu, dicatat pula hal hal yang menyangkut penerapan panduan TPTI.

\section{Analisis Data}

\section{Persentase pohon yang rusak}

Untuk mengetahui persentase pohon yang rusak (berdiameter $20 \mathrm{~cm}$ dan ke atas) bagi kedua HPH tersebut adalah dengan mencari gambaran kerusakan tegakan yang diperolith dari analisis tabulasi dan dari hasil -perbandingan jumlah pohon rusak (termasuk roboh dan hilang) terhadap jumlah pohon mula-mula dikurangi jumlah pohon yang ditebang, selanjutnya dianalisis dengan uji $\mathbf{T}$.

\section{Hubungan antara jumlah pohon yang Ditebang} dengan Tingkat Kerusakan Tegakan Tinggal

Model umum yang digunakan adalah :

$\mathbf{Y}=\mathbf{a}+\mathbf{b X}+\mathrm{E}$, di mana :

$Y=$ tingkat kerusakan tegakan tinggal (\%).

$\mathrm{X}=$ jumlah pohon yang ditebang (ph/ha)

$\mathrm{a}, \mathrm{b}=$ parameter regresi

$\Sigma \sim \operatorname{NID}\left(0, \sigma^{2}\right)$.

Untuk melihat peranan faktor jumlah pohon ditebang terhadap tingkat kerusakan tegakan tinggal, dilakukan sidik regresi.

\section{HASIL DAN PEMBAHASAN}

Berdasarkan jenis peralatan yang digunakan untuk kegiatan-kegiatan utama, yaitu : penebangan, penyaradan dan pengangkutan, maka kedua HPH yang diteliti dapat dikelompokkan ke dalam perușahaan mekanis penuh. Karena untuk penyaradannya digunakan traktor, maka lajim disebut eksploitasi sistem traktor.

\section{A. Persentase pohon yang rusak}

Untuk melihat besarnya persentase pohon yang rusak akibat pemanepan hasil hutan, maka dapat dilihat pada Tabel 1 berikut.

Tabel 1 kolom 2 menyajikan gambaran rata-rata jumlah pohon jenis perdagangan berdiameter $20 \mathrm{~cm}$ dan ke atas sebelum pelaksanaan pemanenan yang berkisar antar 65 pohon sampai 96 pohon per ha untuk HPH A dan 58 pohon sampai 91 pohon per ha untuk HPH B. Pada kolom 3 terlihat gambaran jumlah pohori setelah pelaksanaan pemanenan atau gambaran keadaan tegakan tinggal dari jenis perdagangan dengan rat-rata 71,5 pohon untuk HPH A dan 63 pohon untuk HPH B per ha. Apabila dipadankan dengan panduan sistem. TPTI khususpaya persyaratan banyaknya pohon inti yang ditnggalkan, di mana untuk pohon inti berdiameter 20 $\mathrm{cm}$ ke atas diperlukan 25 pohon/ha, maka kedua HPH ini masih memenuhi persyaratan jumlah pohon inti yang ditinggalkan namum jelas dapat dikemukakan bahwa, 
Tabel 1. Persentase Pohon yang Rusak. Jenis Perdagangan berdiameter $20 \mathrm{~cm}$ ke atas Akibat Kegiatan Penebangan di dua HPH per ha

Table 1. The Effect 'of Logging Activity on Percentage of Commercial Trees Damaged with Diameter $20 \mathrm{~cm}$ and up in Two Forest Concession per ha

\begin{tabular}{|c|c|c|c|c|c|}
\hline Nama HPH & $\begin{array}{l}\text { Keadaan tegakan } \\
\text { Stand condition }\end{array}$ & $\begin{array}{l}\text { Sebelumpetipa- } \\
\text { nenan (pohon) } \\
\text { Before logging } \\
\text { (trees). }\end{array}$ & $\begin{array}{l}\text { Setelah pema- } \\
\text { nenan (pohon) } \\
\text { After logging } \\
\quad \text { (trees) }\end{array}$ & $\begin{array}{l}\text { Ditebang } \\
\text { (pohon/ha) } \\
\text { Felled } \\
\text { (tree/ha) }\end{array}$ & $\begin{array}{c}\text { Persentase pohon rusak (\%) } \\
\text { Percentage of damaged trees } \\
\text { (\%) }\end{array}$ \\
\hline$\dot{A}$ & $\begin{array}{r}1 \\
2 \\
3 \\
4 \\
5 \\
6 \\
7 \\
8 \\
9 \\
10\end{array}$ & $\begin{array}{l}96 \\
82 \\
91 \\
85 \\
87 \\
79 \\
81 \\
93 \\
68 \\
65\end{array}$ & $\begin{array}{l}83 \\
68 \\
79 \\
73 \\
76 \\
78 \\
70 \\
76 \\
57 \\
55\end{array}$ & $\begin{array}{r}9 \\
11 \\
10 \\
8 \\
9 \\
8 \\
7 \\
12 \\
8 \\
7\end{array}$ & $\begin{array}{l}4,6 \\
4,2 \\
4,6 \\
3,9 \\
2,6 \\
4,2 \\
5,4 \\
6,2 \\
5,0 \\
5,2\end{array}$ \\
\hline $\begin{array}{l}\text { Jumlah (Total) } \\
\text { Rata-rata (Mean) }\end{array}$ & & $\begin{array}{l}827 \\
82,7\end{array}$ & $\begin{array}{c}713 \\
71,3\end{array}$ & $\begin{array}{c}89 \\
8,9\end{array}$ & $\begin{array}{r}45,9 \\
4,59\end{array}$ \\
\hline$\overline{\mathbf{B}}$ & $\begin{array}{r}1 \\
2 \\
3 \\
4 \\
5 \\
6 \\
7 \\
8 \\
9 \\
10\end{array}$ & $\begin{array}{l}87 \\
76 \\
61 \\
59 \\
90 \\
58 \\
69 \\
70 \\
85 \\
91\end{array}$ & $\begin{array}{l}72 \\
64 \\
52 \\
52 \\
76 \\
51 \\
59 \\
57 \\
70 \\
77\end{array}$ & $\begin{array}{r}10 \\
8 \\
6 \\
5 \\
9 \\
5 \\
7 \\
9 \\
10 \\
9\end{array}$ & $\begin{array}{l}6,5 \\
5,9 \\
5,4 \\
3,7 \\
6,2 \\
3,8 \\
4,8 \\
6,6 \\
6,6 \\
6,1\end{array}$ \\
\hline $\begin{array}{l}\text { Jumlah (Total) } \\
\text { Rata-rata (Mean) }\end{array}$ & & $\begin{array}{l}746 \\
74,6\end{array}$ & $\begin{array}{l}630 \\
63,0\end{array}$ & $\begin{array}{l}78 \\
7,8\end{array}$ & $\begin{array}{c}55,6 \\
5,56\end{array}$ \\
\hline
\end{tabular}

telah terjadi kerusakan pohon dari keadaan semula dan hal ini terlihat pada kolom 5.

Pada kolom 5. terlihat bahwa, rata-rata persen pohon yang rusak per ha berkisar antara $2,6 \%$ sampai $6,2 \%$ untuk HPH A dan 3,7 \% sampai 6,6\% untuk HPH B hal ini untuk jumlah pohon ditebang antara 7 sampai 12 ph/ha untuk HPH A dan 5 sampai 10 ph/ha untuk HPH B.

Kemudian dari hasil uji $T$ untuk membandingkan kedua.HPH tersebut dalam hal persentase pohon yang rusak akibat kegiatan pemanenan hasil hutan menghasilkan $t$ hitung $=2,08$ ( $t$ tabel $95 \%=2,10$ ).

Melihat nilai rata-rata persentase pohon yang rusak dari kedua HPH tersebut yang relatif sama, yaitu untuk HPH $A^{\prime}=4,59 \%$ dan HPH $B=5,56 \%$ serta nilai $t$ hitung yang lebih kecil dari $t$ tabel maka dapat dikatakan bahwa, tidak ada perbedaan yang nyata antara kedua HPH tersebut dalam hal persentase pohon yang rusak akibat pemanenan hasil hutan. Dengan perkataan lain, kedua HPH tersebut relatif sama kondisinya dalam melaksanakan kegiatan pemanenan hasil hutan khususnya dalam elemen penebangan dan penyaradan.

Memperhatikahn kembali Tabel 1 kolom 5 tersebut memperlihatkan nilai rata-rata persentase pohon yang rusak dari jenis komersial adalah relatif kecil, namun apabila kerusakan dari jenis non-komersial diperhitungkan, maka tidak menutup kemungkinan nilai persentase kerusakan pohon tersebut akan lebih besar. Menurut pengamatan di lapangan, kemungkinan besarnya kerusakan tersebut dapat mencapai di atas 30 persen. Berhubung adanya keterbatasan dana dan waktu, maka aspek kerusakan pohon dari jenis non-komersial tidak diteliti. Diharapkan untuk diadakan penelitian lanjutannya.

Keadaan tersebut dapat terjadi karena kondisi lapangan dari kedua HPH yang diteliti relatif sama 'dan kurangnya perencanaan dalam kegiatan pemanenan hasil 
' hutan , serta kurangnya pengawasan dari pemerintah, sehingga persentase kerusakan pohon (tegakan tinggal) yang rusak dari kedua HRH tersebut relatif sama:

\section{B. Hubungan Antar Jumlah. Pohon Ditebang dengan Kerusakan Tegakan Tinggal.}

Untuk mengetahui peranan faktor jumlah pohon per satuan luas terhadap kerusakan tegakan tinggal, maka akan diperlihatkan hasil analisis data dengan menggunakan regresi linear sederhana antara jumlah pohon ditebang dengan tingkat kerusakan tegakan tinggal per satuan luas.

Dari hasil atialisis regresi didapat $Y=3,91+0,08 \times$ dengan $R=13 \%$. Selanjutnya untuk melihat faktor jumlah pohon yang ditebang terhadap tingkat kerusakan tegakan tinggal menghasilkan nilai Fhitung $=0,14$ (Ftabel $95 \%=5,32$ ).

Berdasarkan hasil-hasil di atas, maka semakin jelaslah bahwa, dalam kasus di kedua HPH ini jumlah pohon ditebang per satuan luas tidak berpengaruh nyata terhadap kerusakan tegakan tinggal. Dengan lain perkataan, kedua HPH ini dalam melaksanakan kegiatan pemanenan hasil hutannya berlangsung berdasarkan kurangnya perencanaan yang meskipun relatif sedikitnya kerusakan tegakan tinggal yang terjadi (hanya dari jenis komersial) dan terpenuhinya jumlah pohon inti yang ditinggalkan.

Keadaan tersebut dapat terjadi karena beberapa hal, seperti :

1. Kondisi lapangan dari kedua HPH tersebut di mana pohon-pohon yang akan ditebang umumnya berada di tempat-tempat yang relatif curam, karena itu kegiatan penebangan gkan berpusat di tempat tersebut dan akan mempengaruhi besarnya kerusakan tegakan tinggal yang bakal terjadi.

2. Dalam penelitian ini hanya mencakup kerisakan tegakan tinggal yang terjodi dari jenis perdagangan (komersial) yang berdinanter $20 \mathrm{~cm}$ dan ke atas, sedanghan beberapa hasil penelitian Thaib (1985, 1986a, 1986b) serta Thaib dan Suhartana (1991) yang berkesimpulan bahwa, semakin banyak jumlah pohon yang ditebang per satuan luas, maka akan semakin tinggi pula kerusakan tegakan tegakan tinggal yang bakal terjadi, mencakup kerusakan tegakan tinggal dari jenis perdagangan dan bukan perdagangan (non komersial) yang berdiameter $20 \mathrm{~cm}$ dan ke atas.

3. Kegiatan pemanenan hasil hutan yang diteliti hanya meliputi elemen pepebangan dan penyaradan, sehingga apabila kegiatan pemanenan hasil hutan yang lainnya dilakukan seperti pembukaan wilayah hutan (PWH), kemungkinan besar kerusakan tegakan tinggal yang bakal terjadi akan semakin tinggi.

\section{KESIMPULAN DAN SARAN}

1. Rata-rata persentase kerusakan pohon akibat kegiatan pematienan hasil hutan adalah $4,6 \%$ untuk HPH A dan 5,6 \% untuk HPHB untuk rata-rata jumlah pohon ditebang $8,9 \mathrm{ph} / \mathrm{ha}$ untuk HPH $\mathrm{A}^{\prime}$ dan $7,8 \mathrm{ph} / \mathrm{ha}$ untuk HPH B.

2. Jumlah pohon ditebang persatuan luas tidak berpengaruh nyata terhadap tingkat kerusakan tegakan tinggal, karena kondisi lapangan yang relatif sama dan kurangnya pengawasan dari pemerintah serta belum adanya perencanaan pemanenan hasil hutan yang baik.

3. Perlu penetitian lanjutan untuk berbagai kondisi lapangan serta dimasukannya jenis pohon nonkomersial dalam perhitungan kerusakan pohon.

\section{DAFTAR PUSTAKA}

Ewel, J \& L. Conde, 1978. Environmental Implication of any Species Utulization in The Moist Tropics. Proc. of Conference on Improved Utilization of Tropical Forest. Forest Lab. Forest Service US Dept. of Agriculture, p. 106-123.

Letourneau, L. R., 1979. Influencing Logging System. Forest News for Asia Pacitic Vol:3, p. 66-68.

Sinden, J. A., 1978. Evaluation and Analysis of Environmental Impacts of Forestry. Kongres Kehutanan Sedunia VIII. Jakarta, Indonesia.

Thaib, J., 1985. Pengaruh Penggunaan Traktor terhadap Tegakan Tinggal pada Beberapa Pengusahaan Hutan di Kalimantan Timur. Jurnal Penelitian Hasil Hutan Vol. 2 No. 3, p. 10-14 Bogor.

1986a. Kerusakan Tegakan Sisa Akibat Eksploitasi dengan Sistem Traktor dan Highlead. Jurnal Penelitian Hasil Hutan Vol. 2 No. 4, p. 1418. Bogor.

-.-, 1986b. Pengarub Intensitas. Penebangan dan Lereng terhadap Keterbukaan Tanah. Jurnal Penelitian Hasil Hutan Vol. 9 No. 4, p. 28-32. Bogor.

Thaib, J dan S. Suhartana., 1991. Keadaan Jalan Sarad dan Pohon Ditebang pada Tegakan Tinggal di Kawasan Sebuah Perusahaan Hutan di Riau. Jurnal Penelitian Hasil Hutan Vol. 9 no. 4, p. 144-149. Bogor. 